Overseas aid policy needs better science input, inquiry finds

Jim Giles, London

The British government's foreign-aid department looks set to appoint a chief scientist, after being criticized for how it uses science.

Senior academics found fault with the Department for International Development's research programmes at an inquiry begun in January by the House of Commons Science and Technology Select Committee. The department currently spends $\mathfrak{E} 80$ million (US\$150 million) a year on research in areas such as agriculture and health, with the aim of reducing poverty in poorer nations. Most of the money is distributed as grants to research institutions in Britain and, increasingly, developing countries.

At one of the committee's hearings on 15 March, for example, John Lawton, chief executive of the Natural Environment Research Council, a government funding body, was asked to sum up the department's use of scientific advice in a few words. He chose "complacent", "rather arrogant" and "ill-informed".

Paul Spray, the department's head of research, rejects Lawton's characterization, pointing out that he and other officials meet regularly with people in the research councils to discuss funding programmes. He acknowledges that his staff could interact more with individual scientists, but says a recruitment drive to increase research staff numbers from 7 to 17 should help to rectify this.

The department has asked a threeman task force to examine how it gets advice on science and technology. Sources close to the department and the team, which started work in April and is due to finish in June, say it is likely to recommend the creation of a post of chief scientist. The department will also ramp up its research funding to at least $\mathfrak{E} 100$ million a year in 2006-07. Its draft research strategy, released on 11 May, identified four priority areas - agricultural productivity in Africa, killer diseases, countries that work in the interests of the poor, and climate change.

The strategy was welcomed by UK overseas development experts, but critics said it included little direct input from scientists - a complaint Spray accepts. He says that in some areas, such as agricultural science, he has been able to identify science organizations that share the department's aim of reducing poverty, but that collaboration in other areas is hampered by a lack of suitable partners.

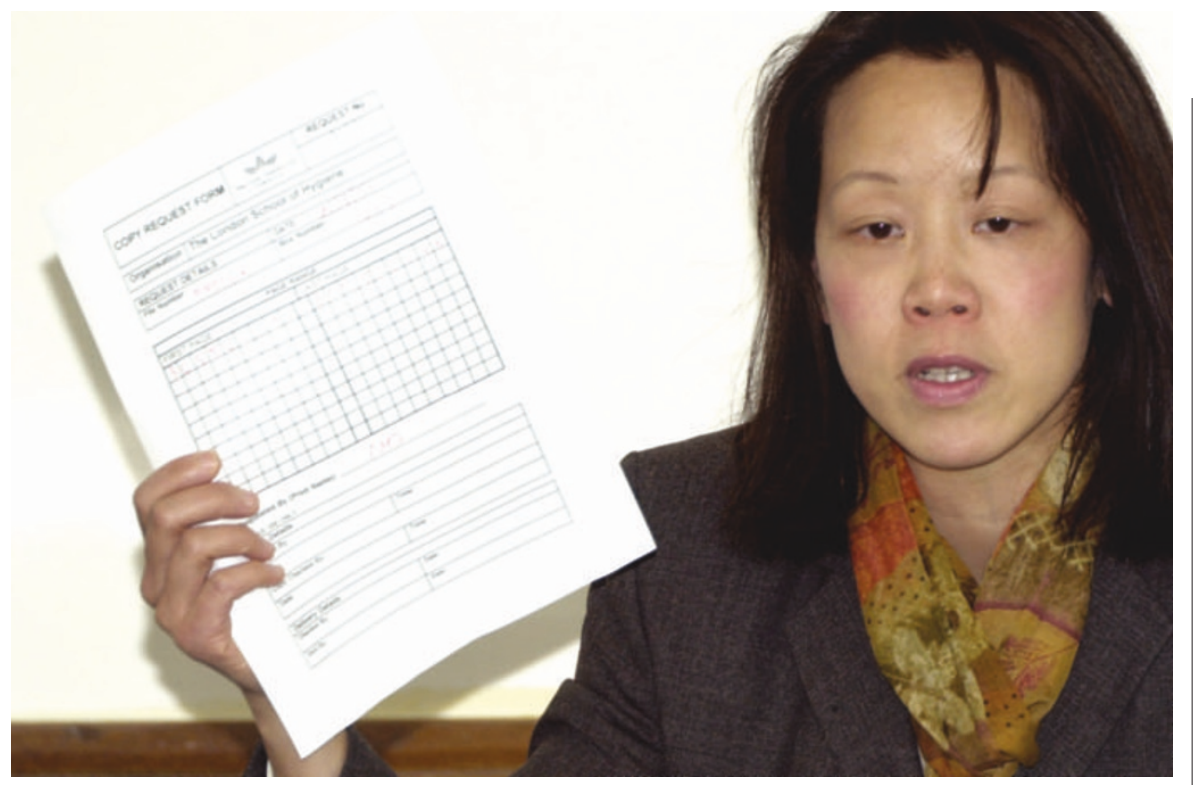

Project member Kelley Lee brandishes one of 40,000 forms submitted to access BAT’s depository.

\title{
Researchers seize moment to make tobacco data public
}

\section{Michael Hopkin, London}

Public-health researchers have unveiled a project to tackle what they describe as information concealment by the UK-based multinational firm British American Tobacco (BAT). The group aims to publish some 8 million pages of the company's documents on an independent website, making them more easily accessible.

The researchers accuse BAT of obstructing public attempts to access papers at its depository in Guildford, UK, and allege that some files detailing the company's activities have been removed or altered. The facility, they say, limits visitor numbers, doesn't provide an easily searchable index of its material, and does not allow onsite photocopying of documents. Visitors must request copies from BAT, which can take up to 12 months to arrive.

"This sort off conduct raises questions as to the true public availability of the depository's contents," says Kelley Lee, a public-health expert at the London School of Hygiene and Tropical Medicine and a project member.

BAT denies that any files have been deleted. Regarding access to the depository, "it was never designed to work like a public library", says Michael Prideaux, BAT's corporate and regulatory affairs director. $\mathrm{He}$ adds that researchers are welcome to reproduce material given to them by BAT.

The depository was opened in 1999 in response to a 1998 settlement between the state of Minnesota and the tobacco industry, which mandated that the documents be made available to the public. In accordance with the ruling, US-based defendants have their Minnesota repository administered by an independent legal firm, but BAT runs its Guildford depository itself.
In 2000, a British government committee recommended that BAT publish the depository's entire contents on the Internet to facilitate access. But so far the company has only stored 350,000 pages electronically, and has not posted those online.

The $£ 2$-million (US\$3.6-million) initiative, called the Guildford Archiving Project, is backed by a slew of public-health organizations, including the Wellcome Trust and the American Heart Association. Together they have ordered copies of the depository's entire contents, which involved completing more than 40,000 order forms. They aim to post them, fully indexed, on a website run by the University of California, San Francisco.

The project's leaders claim that, since researchers began visiting the depository in 2000, more than 180 sets of documents, totalling some 36,000 pages, have disappeared from the company's list of files.

In this week's issue of The Lancet, a group of the project's researchers describes how documents originally referring to marketing to 16-year-olds were altered to read "18-yearolds” instead (M. E. Muggli, E. M. LeGresley and R. D. Hurt Lancet 363, 1812-1819;2004).

They also claim that an audio recording about a marketing strategy was later deleted, removing phrases such as: "if you just say, this is a cheap cigarette for you dirt poor little black farmers ... they're not going to go for it." The deletion may have been accidental, they add, and a master copy was provided on request. But the incident highlights how some information may go missing, they say.

BAT spokeswoman Teresa La Thangue denies that any documents have been removed, and says that the apparently missing documents were probably duplicates. 